\title{
Exploration and Practice of Ideological and Political Theories Teaching in Operations Research Courses Based on the "Trinity"
}

\author{
Rong Liu* \\ College of Port and Shipping Management, Guangzhou Maritime University, Guangzhou 510725, China \\ *Corresponding author: Rong Liu, 121712170@qq.com
}

\begin{abstract}
This study analyzes the background of ideological and political theories teaching in operations research courses and provides a design framework for ideological and political theories teaching in operations research courses based on "trinity" according to real teaching practices. This article summarizes the merging point of ideological and political theories teaching in operations research courses, taking ability and knowledge as its carrier and ideological and political theories teaching as its core, as well as discusses four methods of ideological and political theories teaching: online and offline interactive teaching, stimulating independent learning by practical application, seminar-style flipped classroom, and promoting theoretical teaching through competition and scientific research.
\end{abstract}

Keywords: Operations research; Ideological and political theories teaching; Trinity; Teaching practice

Publication date: November 2021; Online publication: November 30, 2021

\section{Introduction}

In June 2020, the Ministry of Education issued the Guiding Outline for the Ideological and Political Construction of All Courses in Colleges and Universities and explicitly pointed out that "we must profoundly understand the strategic significance of promoting ideological and political construction in all courses, give full play to the role of the "main force"; i.e., the teachers of professional courses, the "main field"; i.e., the teaching of professional courses, and the "main channel"; i.e., the classroom teaching of professional courses, as well as ensure the simultaneous development of professional courses and ideological and political courses, so as to build a long-term mechanism for moral cultivation." This does not only put forward higher requirements for ideological and political education in colleges and universities, but also new requirements, new directions, and a new trial for professional courses.

Operations Research is the core professional course of management and engineering. Taking Guangzhou Maritime University as an example, it covers logistics management, logistics engineering, transportation, traffic management, marine engineering, navigation engineering, ship engineering, etc., thus attracting a fair number of students. Operations Research courses involve the application and improvement of previous courses, including linear algebra, probability theory, mathematical statistics, survey courses, and basic computer classes. The course lays a solid foundation for advance core professional courses, such as planning and design, simulation and operation management of logistics and transportation system, as well as its practice. The teaching content of Operations Research mainly includes linear programming, integer programming, dual programming, transportation planning, graph and network optimization, queuing theory, storage theory, etc. Therefore, it is necessary to establish mathematical models for various practical problems, solve the models through algorithms, and finally provide quantitative basis for decision- 
making.

At present, most engineering courses have the problem of emphasizing "Shu" while neglecting "Tao"; that is, teachers focus on imparting knowledge but neglect the elucidation and promotion of moral values. At the same time, limited by the characteristics of some courses, it is difficult to integrate ideological and political theories teaching into professional courses. This results in the isolation of ideological and political education ${ }^{[1]}$. In order to realize the "trinity" teaching objectives of knowledge, ability, and quality in the teaching process, it is essential to hold onto the idea of "treating motherland, people, and responsibility as priorities" throughout the whole process of professional course teaching and avoid the simple teaching and explaining model. It also requires the careful design and constant exploration by professional teachers on the basis of comprehensive research on professional contents and the process of its production as well as its development. Only in this way, the goal and concept of ideological and political education can be truly practiced as naturally as "dissolving salt in water" and "moisturizing things silently" [2].

\section{The design framework of ideological and political theories teaching in Operations Research courses}

The design framework of Operations Research adheres to the teaching concept of "trinity" and emphasizes the grasp of knowledge as well as the improvement of ability and morality. It also stresses on the integration of the requirements of socialist core values as well as Marxism-Leninism and materialist world outlook and values into the course teaching. The design idea is shown in Figure 1.

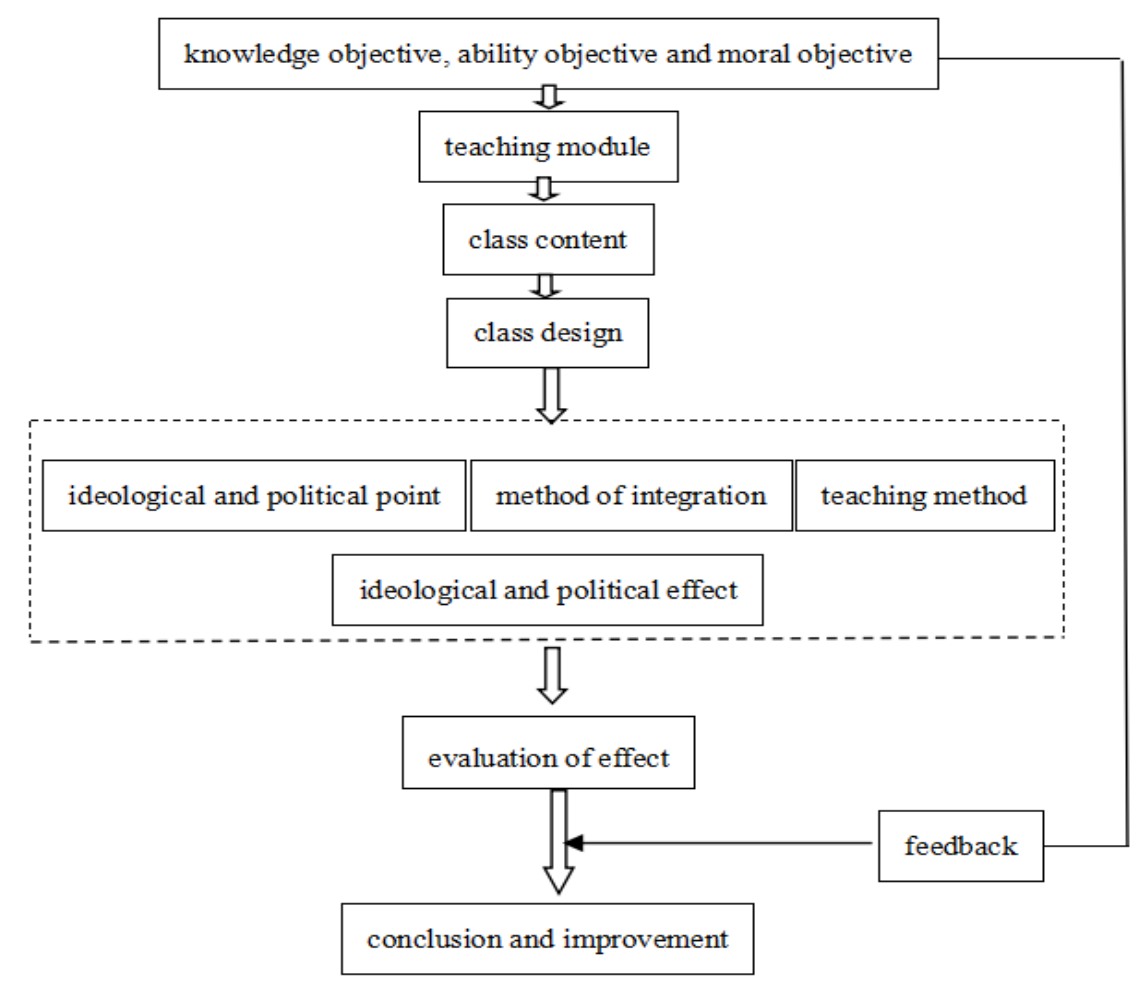

Figure 1. Design idea of ideological and political theories teaching in Operations Research

First of all, the "trinity" is emphasized in the course design process. The three objectives of each chapter and each lesson are decomposed, as shown in Figure 2. The teaching content is integrated, and the explanation of theoretical knowledge and value guidance are emphasized at the same time. Second, ideological and political education resources are mined and embedded in the process of modeling, looking for methods and drawing conclusions, as well as preparing lessons and correcting homework. Ideological and political elements are infiltrated into knowledge points through teachers' words and deeds. Third, 
through excellent massive open online courses (MOOCs) and interactive question and answer (Q\&A) platforms, the integrated teaching mode of online and offline interactive teaching is designed to expand the course information and better satisfy students' requirements for knowledge. Finally, the standard for evaluating the ideological and political teaching effect is established according to the nature of the Operations Research course, its teaching content, and teaching process.

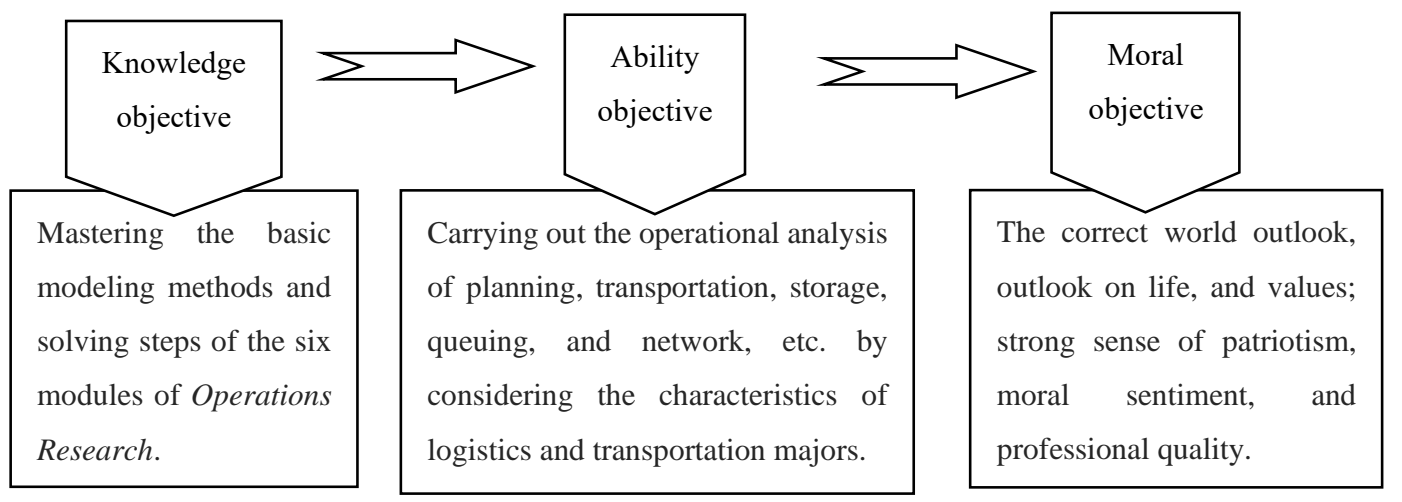

Figure 2. Course objectives of Operations Research

The teaching design of the core content required in the syllabus is carried out by centering on the syllabus and based on the content modules, as shown in Figure 3. The decision theory and queuing theory in the dotted box are adjusted according to the arrangement of professional hours.

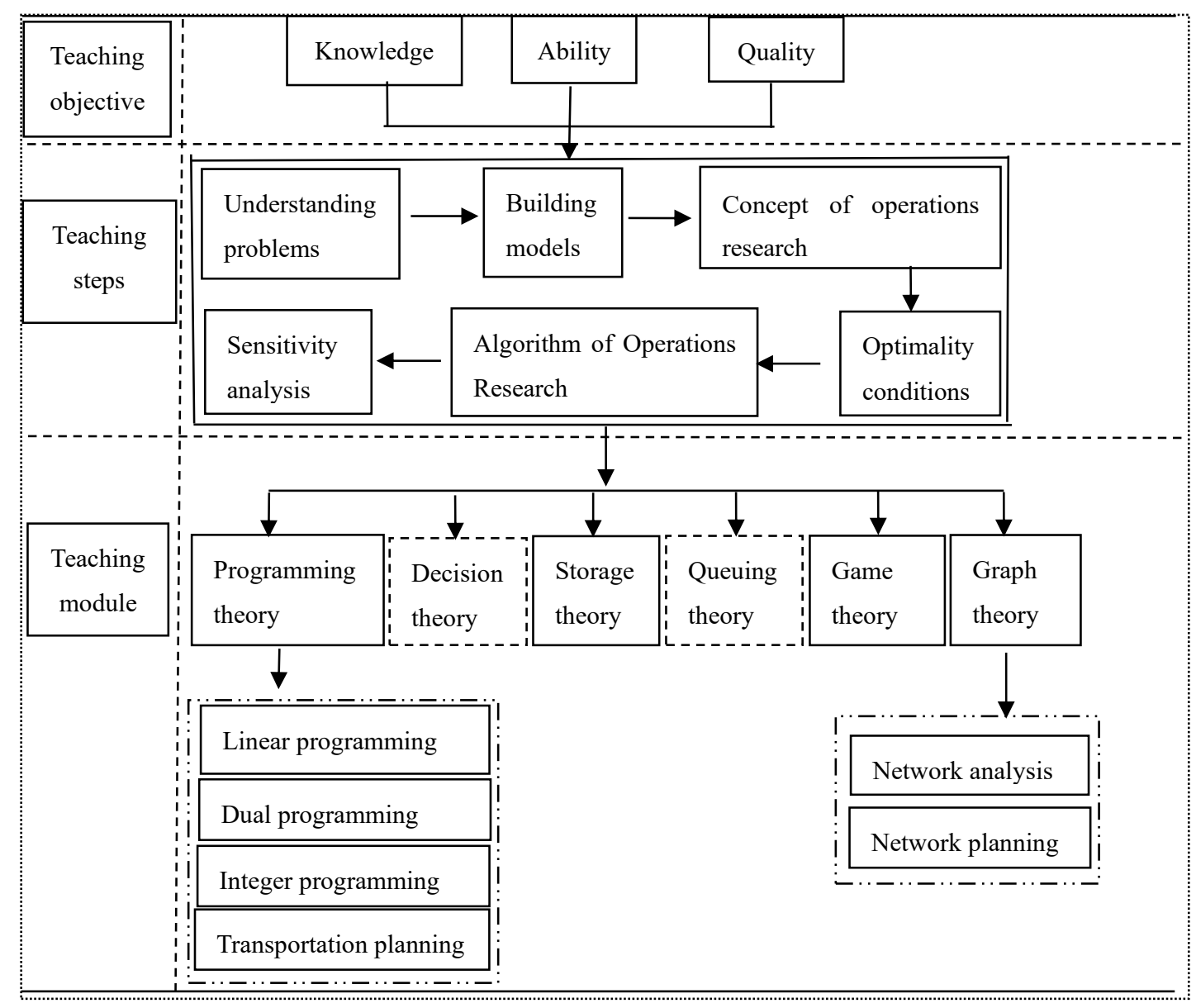

Figure 3. Teaching content of Operations Research 


\section{The "Trinity" integration of ideological and political theories teaching in Operations Research}

The integration of ideological and political theories teaching should overcome the separation of knowledge and ability, avoid superficial explanation, pursue the deep integration of visible knowledge and ability with invisible ideological and political theories, as well as strengthen the educational function of courses; that is, "moisturizing things silently." Table 1 shows a part of the "trinity" integration of ideological and political theories teaching implemented by the author in his teaching group. The knowledge and ability of operations research are taken as the carrier, while ideological and political theories teaching is assumed as the core, aiming to cultivate strict scientific thinking, rigorous academic thinking, scientific engineering thinking, and creative thinking among the students, foster their senses of national pride and patriotic sentiments, promote the organic integration of qualities, such as integrity, kindness, ideals, beliefs, correct outlook on life, world outlook, and values, so as to cultivate innovative talents who would strive for the prosperity of the nation and the country ${ }^{[3]}$.

Table 1. The "trinity" integration of ideological and political theories teaching in Operations Research

\begin{tabular}{|c|c|c|}
\hline Knowledge & Ability & Ideological and political quality \\
\hline $\begin{array}{l}\text { Introduction to } \\
\text { operations } \\
\text { research }\end{array}$ & $\begin{array}{l}\text { (1) Operational thinking reflected in Sun Tzu's Art } \\
\text { of War, Shen Kuo's method of grain transport, and } \\
\text { Ding Wei's thoughts on palace construction. } \\
\text { (2) Origin of operations research. } \\
\text { (3) Operational research algorithms by Hua Luogeng } \\
\text { and Mei Guangu. }\end{array}$ & $\begin{array}{l}\text { The cognition of national culture and the } \\
\text { cultivation of national confidence. }\end{array}$ \\
\hline $\begin{array}{l}\text { Graphical method } \\
\text { for linear } \\
\text { programming } \\
\text { (LP) problem }\end{array}$ & $\begin{array}{l}\text { (1) Determining the contour line of the objective } \\
\text { function value and its direction of growth according } \\
\text { to the objective function. } \\
\text { (2) Moving the contour line for optimal solution. }\end{array}$ & $\begin{array}{l}\text { (1) The cognition of the philosophy of } \\
\text { "interconversion between quality and quantity." } \\
\text { (2) The cognition of "phenomenon and essence." }\end{array}$ \\
\hline Simplex method & $\begin{array}{l}\text { The jump solution is carried out within a feasible } \\
\text { range. If there is no feasible range, no matter how } \\
\text { good the objective is, it cannot be realized. If there is } \\
\text { an unbounded feasible range, it would not reach the } \\
\text { optimal one either. }\end{array}$ & $\begin{array}{l}\text { The recognition of rules and boundaries: there } \\
\text { are laws in the country, and rules in the family; } \\
\text { the greatest challenge for a country lies not in } \\
\text { making laws but in putting those laws into effect; } \\
\text { not in listening to the advice of the public, but in } \\
\text { really accepting these suggestions. }\end{array}$ \\
\hline $\begin{array}{l}\text { Big } \mathrm{M} \text { method } \\
\text { and two-phase } \\
\text { method }\end{array}$ & $\begin{array}{l}\text { After the addition of artificial variables, the initial } \\
\text { base is built with artificial variables, and finally the } \\
\text { influence of artificial variables is removed. }\end{array}$ & $\begin{array}{l}\text { The understanding of shortcuts: there is no } \\
\text { shortcut in life; one needs to pursue the set goal } \\
\text { step-by-step. }\end{array}$ \\
\hline $\begin{array}{l}\text { The proposition } \\
\text { and basic } \\
\text { properties of the } \\
\text { duality theory }\end{array}$ & $\begin{array}{l}\text { (1) The proposal of duality problem reflects the } \\
\text { nature of two different angles on one thing. } \\
\text { (2) The strong duality theorem reflects that the best } \\
\text { game point for the seller and the buyer is actually the } \\
\text { best interest point for both sides. }\end{array}$ & $\begin{array}{l}\text { The recognition of philosophical methodology } \\
\text { and values: everything has two sides; the best } \\
\text { way to avoid internal friction is to avoid being } \\
\text { isolated, be open-minded, and share information. }\end{array}$ \\
\hline Shadow price & $\begin{array}{l}\text { Shadow price reflects the internal scarcity of } \\
\text { resources and the reasonable allocation of prices. } \\
\text { Compare shadow prices with market prices. }\end{array}$ & $\begin{array}{l}\text { The understanding of the wise leadership of the } \\
\text { Communist Party of China: the transformation of } \\
\text { economy from a high-speed growth stage to a } \\
\text { high-quality development stage. }\end{array}$ \\
\hline
\end{tabular}

Continued on the next page 


\begin{tabular}{|c|c|c|}
\hline Knowledge & Ability & Ideological and political quality \\
\hline $\begin{array}{l}\text { Sensitivity } \\
\text { analysis }\end{array}$ & $\begin{array}{l}\text { Study on the stability of the optimal solution when } \\
\text { the data changes; determine which parameters have } \\
\text { the greatest impact on the system or model. }\end{array}$ & $\begin{array}{l}\text { The perception of continuous learning and } \\
\text { sustainable development: continuous learning } \\
\text { and ability improvement is the purpose and } \\
\text { motivation of sensitivity analysis. }\end{array}$ \\
\hline $\begin{array}{l}\text { Model of } \\
\text { transportation } \\
\text { problems }\end{array}$ & $\begin{array}{l}\text { Application of transportation problems in real life, } \\
\text { and the introduction of the transportation problem } \\
\text { model. }\end{array}$ & $\begin{array}{l}\text { The recognition of China's transportation } \\
\text { achievements: "to be rich, build a road first"; } \\
\text { roads are the top priority in infrastructure } \\
\text { construction. }\end{array}$ \\
\hline $\begin{array}{c}\text { Imbalance } \\
\text { between } \\
\text { production and } \\
\text { marketing } \\
\end{array}$ & $\begin{array}{l}\text { ace between production and marketing } \\
\text { d only when it is balanced on both sides. }\end{array}$ & $\begin{array}{l}\text { Introducing Xunzi's idea of "two things are kept } \\
\text { balanced when they are at a horizontal level"; } \\
\text { understanding the concept of "harmony and } \\
\text { equality" in the socialist core values. }\end{array}$ \\
\hline $\begin{array}{l}\text { Branch-and- } \\
\text { bound method for } \\
\text { integer } \\
\text { programming }\end{array}$ & $\begin{array}{l}\text { The process of branching is the process of } \\
\text { adding child nodes in treeview; delimitation is to } \\
\text { check the upper and lower bounds of sub-problems } \\
\text { in the process of branching. }\end{array}$ & $\begin{array}{l}\text { Mastering the methodology of cognitive process } \\
\text { from abstract to concrete, from far to near, and } \\
\text { step-by-step. }\end{array}$ \\
\hline $\begin{array}{l}\text { Assignment } \\
\text { problem of } \\
\text { integer } \\
\text { programming }\end{array}$ & $\begin{array}{l}\text { (1) Modeling conditions for assignment problems. } \\
\text { (2) In the Hungarian method, the one that is more } \\
\text { selective should give way to the one that is less } \\
\text { selective. }\end{array}$ & $\begin{array}{l}\text { (1) The cultivation of professional dedication and } \\
\text { sense of professional mission. } \\
\text { (2) The deep connotation of comity. }\end{array}$ \\
\hline $\begin{array}{l}\text { Shortest path } \\
\text { problem }\end{array}$ & Iterative algorithm for shortest path problem. & $\begin{array}{l}\text { A belief in life that takes a long-term view } \\
\text { despite difficulties. }\end{array}$ \\
\hline $\begin{array}{l}\text { Chinese postman } \\
\text { problem }\end{array}$ & $\begin{array}{l}\text { The Chinese postman problem is one of the famous } \\
\text { problems of graph theory. }\end{array}$ & $\begin{array}{l}\text { Paying tribute to Guan Meigu, Qian Xuesen, and } \\
\text { other outstanding Chinese operational } \\
\text { researchers. }\end{array}$ \\
\hline $\begin{array}{l}\text { Critical path } \\
\text { method }\end{array}$ & Calculation of time parameters of critical routes. & Recognizing the importance of teamwork. \\
\hline $\begin{array}{c}\text { Network } \\
\text { optimization }\end{array}$ & Time-cost optimization, time-resource optimization & $\begin{array}{l}\text { Cultivating the thinking of systematic } \\
\text { coordination as well as multilateral and win-win } \\
\text { results. }\end{array}$ \\
\hline Game & $\begin{array}{l}\text { (1) Understanding the connotation of operational } \\
\text { gaming. } \\
\text { (2) Integrating Nash and John von Neumann's story: } \\
\text { a life of tragedy and wonder. }\end{array}$ & $\begin{array}{l}\text { (1) Understanding the core of game theory: using } \\
\text { one's strengths against the opponents' } \\
\text { weaknesses. } \\
\text { (2) Correctly understanding the suffering of life } \\
\text { and cultivating confidence in the chosen path. }\end{array}$ \\
\hline
\end{tabular}

\section{Teaching measures of ideological and political theories teaching in Operations Research}

Ideological and political theories teaching in Operations Research can effectively promote the reform and innovation of teaching methods, not only focusing on the single mode of imparting professional knowledge, but also exploring and practicing various methods of integration and teaching. 


\subsection{Online and offline interactive teaching}

It uses online and offline hybrid teaching mode and builds teaching resources based on multimedia, multiplatforms, and multi-channels, realizing educational informatization. It widely uses the latest technologies and platforms to construct curriculum resources as well as emphasizes on the diversity of the forms of classroom teaching and the effectiveness of discourse communication, avoiding compulsory, formalistic teaching style. Moreover, it also makes good use of students' fragmented time ${ }^{[4]}$. Teachers are able to upload videos, audio materials, and questions in advance onto the learning platform for students to study anytime and anywhere. For example, before teaching the technical content of network planning, the teaching team can edit out clips from the documentary, Great Project and Hua Luogeng, showing how patriotic scholars, such as Qian Xuesen and Hua Luogeng, had promoted systems engineering and popularized the dual methods (optimization method and systematical method), in order for students to view in advance.

\subsection{Promoting independent learning by practical application}

In order to stimulate students' initiative and promote the all-round development of students, the teaching team had insisted on collecting, adapting, and introducing hotspots and frontier cases during lessons based on students' requirements and the characteristics of their minds, thus enabling students to carry out the course design with knowledge in operations research. For example, against the context of the global pandemic, students can look for information and learn relative software independently to optimize the allocation of medical resources as well as the layout and location of transfer stations for scarce supplies. This helps them understand the practical application of operations research, so as to stimulate their learning enthusiasm and cultivate their independent learning ability.

\subsection{Seminar-style flipped classroom}

Teachers have been carrying out seminar-style teaching based on flipped classroom, such as the analysis and optimization of production plan in an automobile assembly workshop and the mathematical model for solving actual cases by applying the methods involved in operations research. Both require teamwork for completion. During class discussions, students are encouraged to raise questions and debate on their answers ${ }^{[5]}$. Based on the error-correction mechanism, students are encouraged to discover and solve problems independently. After each lesson, teachers and students would summarize and forecast the lesson together, analyze the shortcomings, and put forward measures for improvement while emphasizing on seeking truth from facts, unity, cooperation, and being positive despite difficulties.

\subsection{Promoting theoretical teaching by competition and research}

In the teaching process, based on the author's own experience in guiding his students in competition and research, practical cases related to operations research are usually shared, such as college students' innovation and entrepreneurship projects, national college students' mathematical modeling, logistics innovation and entrepreneurship competition, and other related research topics. For example, studies on obstacle avoidance and path planning with sensor based on an improved ant colony algorithm, the design scheme of intelligent unmanned cold chain logistics, and the terminal logistics mode selection of a Guangzhou-based auto parts B2B e-commerce platform ${ }^{[6]}$. Groups that excel are encouraged to participate in practical activities and research. This does not only stimulate students' interest in learning, but also cultivate their ability to solve practical problems. 


\section{Conclusion}

Ideological and political theories teaching in courses is an implicit kind of ideological and political education, which is the result of the joint action of educational idea and teaching practice. This study combed the ideological and political merging point based on the "trinity" in Operations Research and discussed several methods of integration and teaching practices, endeavoring to implement the fundamental task of moral education into each step of teaching and to realize the organic integration of ideological and political education into the teaching of professional knowledge.

\section{Funding}

This study was supported by the Teaching Quality and Teaching Reform Project Logistics Engineering Key Major of Guangdong Provincial Undergraduate Colleges and Universities (Yue Gao Han [2020] 19); 2021 Teaching Construction Project of Guangzhou Maritime College (Guang Hang Yuan [2021]141); 2020 Industry-University Cooperation Collaborative Education Project (Jiao Gao Si Han [2021] No. 3 202002325060, 202002325052, 202002325050).

\section{Disclosure statement}

The authors declare that there is no conflict of interest.

\section{References}

[1] Song Z, Sun H, 2021, Practice Path and Strategy of Integrated Ideological and Political Theories Teaching in Operations Research Course. Logistics Technology, (8): 157-160.

[2] Wang Y, Shao G, Tao J, et al., 2021, Design and Exploration of Ideological and Political Theories Teaching in Operations Research Course. Journal of Higher Education, (16): 172-176.

[3] Ma M, Liu J, 2021, Research on Ideological and Political Theories Teaching in Operations Research Course. Journal of Higher Education, (35): 176-179.

[4] Liu R, Xiao T, 2020, Teaching Design and Practice of Ideological and Political Theories Teaching in Operations Research Courses in the Post-Epidemic Era. Journal of Inner Mongolia Agricultural University (Social Science Edition), (2): 51-55.

[5] Lu H, Liu H, 2021, Teaching Reform on "Military Operations Research" Based on Ideological and Political Theories Teaching in Courses. Journal of Higher Education Research, (3): 81-85.

[6] Liu R, 2019, Construction of Curriculum System of Applied Logistics Engineering Based on Capability Development. Public Science and Technology, (3): 56-60. 